Beatriz Martins Tavares Murta Jother Soares Machado

Mateus Zaparoli

Vítor Carvalho Lara

Eddie Fernando Candido Murta

\title{
The relationship of host immune cells, cytokine and nitric oxide production to tumor cells in ovarian carcinoma
}

Discipline of Pharmacology, Department of Biological Sciences, Discipline of Gynecology and Obstetrics, Faculdade de Medicina do Triângulo Mineiro, Uberaba, Brazil

\section{ABSTRACT}

Aims: This brief review focuses on the current understanding of the complex relationship of tumorassociated mononuclear cells (TAMs) with neoplastic cells, summarizing their immunological efficiency, cytokine profile and production of nitric oxide ( $\mathrm{NO}$ ) in the tumor microenvironment, with current insights on how this might affect tumor growth.

Data source: Data was obtained through M edline from articles indexed during the last 10 years. The main key words used in the research were: cancer, ovarian cancer, cytokine, nitric oxide ( $\mathrm{NO}$ ), mononuclear cell, lymphocyte, macrophage.

Selection of studies and data collection: 30 studies were reviewed, which contained data regarding the production of cytokines and $\mathrm{NO}$ by TAM s or malignant cells, and tried to establish a correlation between these mediators and tumor growth, especially in ovarian carcinoma.

Data summary: TAM s consist mainly of macrophages and T lymphocytes which present lower proliferative indices and cyto toxicity compared to autologous blood monocytes, although they are able to release various cytokines. The profile of cytokine expression could help to explain both the immunological impairment observed in patients with advanced carcinoma diseases and the potential of TAM $s$ to exert antitumor activity, which makes these cells an attractive target for therapeutic intervention. $\mathrm{NO}$ is also produced in the tumor microenvironment. Several reports in animals suggest a tumoricidal role for $\mathrm{N} O$, but in human tumors its role has not been wellestablished and may change during tumor progression.

Key words: 0 varian carcinoma. Tumor-associated mononuclear cells. Cytokines. $\mathrm{N}$ itric oxide.

\section{REVIEW}

\section{Tumor-associated mononuclear cells (TAM s)}

Solid tumors consist of malignant cells and stroma. Malignant cells elicit stroma formation and this is essential for neoplasia grow th. ${ }^{1} M$ any tumors of epithelial origin contain, in the tumor stroma, a significant number of infiltrating host leukocytes, especially macrophages and lymphocytes. ${ }^{2}$ Also, these cells obtained from neoplastic effusions are extremely useful in evaluating the interactions between immune and cancer cells in the tumor microenvironment. ${ }^{3}$ Phenotypic studies (by flow cytometry) and functional studies of the so-called tumorinfiltrating leukocytes (recovered from tumor) or tumor-associated leukocytes (recovered from malignant effusions) have detected no differences between these cells, ${ }^{3,4}$ which will be referred to here as tumor-associated mononuclear cells (TAM s).

In terms of characterization of the leukocyte infiltrate, ovarian cancer is one of the most extensively studied human tumors. Immunohisto chemistry a na lysis of tissue sections has show $n$ that the cells present in large numbers are mainly macrophages and T cells. ${ }^{2,6}$ B cells, 
natural killer (N K) cells and mast cells are present in low numbers. $\mathrm{N}$ eutrophils are largely confined to blood vessels and eosinophils are seen occasionally. In general, the infiltrating cell density is higher in the stroma than in the tumor compartment. ${ }^{2}$ In peritoneal or pleural effusions secondary to cancers at different sites, including ovarian carcinoma, cells consist mainly of $T$ lymphocytes, but NK cells, B cells and macrophages are also present. It has also been reported that neutrophils are frequently found in the ascites of ovarian carcinoma.

\section{Immunological efficiency of TAM s}

It is not known whether TAM $s$ are a cell population that participates in the immune response against the tumor, or whether these cells might even enhance the development of the tumor. ${ }^{7}$ In this context, it is known that the recruited leukocytes can both recognize and kill malignant cells and establish an immune memory against them or produce factors that help tumor grow th and vascularization through paracrine loops. ${ }^{8}$ The concept of a macrophage balance was introduced by Mantovani et al. to encapsulate the notion that macrophages may aid or inhibit tumor growth according to their state of activation.

In a study of 25 patients with gynecological tumors, of whom 15 had ovarian carcinoma, the autologous peripheral blood mononuclear cells (PBM C S) differed from TAM subset populations in having a significantly higher potential to proliferate in response to mitogen stimulus and also in presenting higher cytotoxicity. ${ }^{7}$ A g reeing with this data, TAM s obtained from peritoneal or pleural effusions secondary to cancer at different sites had a lower proliferative response to mitogens than a utologous PBM C $s$, which in turn was lower than that of control PBMCs, indicating a functional immunological impairment in patients with advanced carcinoma disease.

A nother indicator of the immune state is the pattern of cytokine release by TAMs. M ost of the available data was obtained from advanced ovarian carcinoma. In a recent study, it was found that the cultured supernatants of mitogen-stimulated TAMs produced less IL- $1 \alpha$ and $\beta$, TN F- $\alpha$, IL-4 and IL-10, compared to those of autologous and control PBMCs, as assessed by the ELISA test. $^{3}$ In a similar study, IL-4 was the major cytokine expressed by TAMs, while IFN $-\gamma$ production was predominant in PBM Cs. The analysis of cytokine expression by reverse transcriptase polymerase chain reaction (RT$P(R)$ showed that TAMs had reduced expression of genes for IL-2, IFN $-\gamma$ and IL-4, and inversely, had increased IL-10 gene expression relative to normal PBM Cs. ${ }^{4}$ Taken to gether, these results suggest that the incomplete activation of TAM $\mathrm{s}$ in vivo may be due to the accumulation of Th2 cells instead of Th1 cells, and it is plausible that the increased IL-10 contributes to dow nwards regulation of the Th1 cytokines.

But the role of TAM s studied to date varies considerably, even in ovarian carcinoma. In a study of advanced ovarian carcinoma, TAMs produced appreciable amounts of IL- 6 and spontaneously released significantly higher amounts of IL-8, compared to PBMCs. In patients with ovarian or breast cancer, cyto toxic $T$ cell cultures, isolated from tumors and then further stimulated with autologous tumor cells, lysed these cells and also secreted cytokines such as TNF- $\alpha$, IFN $-\gamma$ and GM-CSF. ${ }^{10}$ In a prospective study of 17 ovarian carcinomas, it was observed that patients in relapse had a significant reduction in TAMs, which were unable to respond to the tumor as evidenced by the correlation between tumor grow th and a decreased number of infiltrating cells.

These differences in cellular composition and the variable prognostic significance of leukocytes that infiltrate many human tumors suggest that different types of interactions are possible between tumor and host cells, possibly resulting in heterogeneous responses. Since TAM $s$ are located at the tumor-host interface and have the potential to exert anti-tumor activity, these cells may constitute an attractive target for therapeutic intervention. 


\section{The role of cytokine expression in the tumor}

Although the role of infiltrating cells in malignant tumors is controversial, a likely stimulus for their presence is the local production of chemokines, so that the leukocyte content of a tumor may depend on the expressed cytokines. In this context, a variety of human and murine tumor cells produce monocyte chemoattractant factors and there is a correlation between the a mount of a ctivity in cultured supernatants and the number of TAMs, when these cells produce tumors in vivo. ${ }^{11}$ Several lines of evidence suggest that monocyte chemoattractant protein-1 (MCP1 ) is an important determinant of macrophage infiltration into tumors (review ${ }^{9}$ ). The presence of messenger RN A for M C P-1 in ovarian carcinoma was first demonstrated by an in situ hybridization technique, ${ }^{11}$ and this study also demonstrated the expression of chemokines such as macrophage inflammatory protein-1 (MIP-1 $\alpha$ ), MIP-1 $\beta$ and RAN TES activity (regulation upon activation: normal $T$ cell expression and stimulation) by these tumors. ${ }^{2}$ Furthermore, a direct topographical association was observed between the number of chemokine-expressing cells and the leukocyte infiltrate at the epithelialstroma interface.

In general, the major components of TAM S have been described as cells resembling Th0 cells, i.e. producing both Th1- and Th2-type cytokines, or with a gradual shift from Th1 to Th2 cells occurring during progressive tumor growth. ${ }^{3}$ The secretion of Th1-like cytokines, as opposed to Th2, could potentially further enhance the endogenous immune response to ovarian cancer. Analysis of cytokine expression using RT-PCR techniques on total RN A isolated from ovarian carcinoma showed that the majority expressed TG F- $\beta$ and IL-10, with absence of expression of IFN $-\gamma$. Half of these tumors expressed GM-CSF and IL-8, which has also been described in vitro. ${ }^{8}$ In accordance with this, higher concentrations of IL-10 have been demonstrated in neoplastic effusions secondary to cancers at different sites, including ovarian carcinoma and, surprisingly, higher IFN - $\gamma$ compared to autologous serum. It is known that IL-10 strongly inhibits the production of TN F- $\alpha$ and $\beta, G M-C S F$ and IFN $\gamma$ by peripheral blood monocytes.

The differences in the expression of cytokines described in the literature may be related to histological types of ovarian carcinoma analyzed in each study. For example, TN F- $\alpha$ and IL-2 are generally described as not being consistently detected in those tumors, in contrast to IL-10 and GM-CSF. The analysis of 13 cases of ovarian carcinomas showed that in only four cases were cells expressing messenger RN A for TN F- $\alpha$ and IL-2 observed, a number considerably lower than that observed in inflammatory conditions such as salpingitis or in normal peripheral lymphoid tissue. ${ }^{12}$ The gene for TN F was studied in biopsies of human epithelial ovarian cancer and a positive correlation was found between TN $F$ expression and tumor grade, suggesting that TN F production may enhance tumor development.

0 varian carcinoma cells produce cytokines that attract monocytes and promote their survival; TAM s in turn produce cytokines which can stimulate cancer cell grow th. So there is an ambivalent relationship between tumor cells and TAMS. In the absence of effective thera peutic intervention, evidence suggests that the balance is shifted in favor of the tumor.

\section{A role for $\mathrm{NO}$ in tumor biology}

$\mathrm{N}$ itric oxide ( $\mathrm{NO})$ is an essential physiological signaling molecule mediating various cell functions, including the cytotoxic/ cytostatic effects of the immune system against debilitating factors like infection and tumor $\left(\right.$ review $^{14}$ ). But, when produced for a long period and in high concentrations, an excess of $\mathrm{NO}$ could damage DN A leading to gene mutations and cancer.

Several human cancers are associated with chronic viral, bacterial and parasitic infections, with $\mathrm{NO}_{16}$ formation being elevated in these infections. ${ }^{16}$ Also, most of the cellular components of the tumor mass (tumor cells themselves and the immune cells infiltrate) have been show $\mathrm{n}$ to generate $\mathrm{N} O$ in vitro (review ${ }^{17}$ ). 
The expression of $\mathrm{N} O$ synthase $(\mathrm{NOS})$ in tumors provokes the question about a physiological role for tumor-associated $\mathrm{N} O$ production.

Several reports suggest a tumoricidal role for $\mathrm{NO}$ in vivo. A chronic inhibition of $\mathrm{NO}$ synthesis with $\mathrm{N}$-monomethyl-L-arginine (L$\mathrm{N} \mathrm{MA}$ ) resulted in increased tumor grow th and delayed immune recognition in mice, implicating endogenous $\mathrm{NO}$ in the impaired a bility of tumor cells to proliferate. ${ }^{18} \mathrm{M}$ oreover, the daily intraperitoneal administration of $L$ N M A prevented the tumoricidal activity in mice which were preinoculated with bacillus Calmette-G uérin ( $B C G$ ) and subsequently transplanted with syngenic or xenogenic ovarian tumor cells. Since it has been demonstrated that $N O$ mediates the BCGinduced host resistance to tumor grafts in mice, it is most likely that $\mathrm{NO}$ accounts for the tumoricidal activity. ${ }^{19}$ Also in mice, the administration of cyto kine-stimulated tumor cells caused a two-fold increase in subcutaneous tumor growth and experimental pulmonary metastases, in relation to control cells. $\mathrm{N}$ monomethyl-L-arginine acetate reduced tumor size and the number of lung metastases to the control levels, suggesting that tumor cell $\mathrm{NO}$ production was responsible for this effect. ${ }^{20}$

In human tumors the role of $\mathrm{NO}$ has not been established. $\mathrm{NO}$ has been reported as being diminished or absent in premalignant lesions and tumors of the large intestine, ${ }^{14}$ while, conversely, an increased level of $\mathrm{NOS}$ expression and/ or activity was observed in human gynecological tumors, and this fact was inversely associated with the differentiation grade of the tumor. ${ }^{21}$ In ovarian cancer, high levels of NOS activity were detected, while the enzyme activity was below detectable levels in gynecological tissue from non-cancer patients. In addition, the immunoreactive proteins in which $\mathrm{N} O \mathrm{~S}$ activity was detected were localized to the tumor cells.

Since cytokines and hypoxia can synergistically induce NOS expression, the premalignant and malignant tumor tissue may establish sustained $\mathrm{N} O$ production in a variety of tumor cells. However, the effect of $\mathrm{NO}$ production in tumor biology may change during tumor progression. ${ }^{21}$ This hypothesis is supported by data investigating the role of $\mathrm{N} 0$ in cancer metastasis. After in vitro incubation with cytokines or LPS, non-metastatic cells exhibited a high level of inducible N O S activity and $\mathrm{N} O$ production, whereas metastatic cells did not. The transfection of tumor cells produced fast-growing and highly metastatic tumors, whereas functional iN O S-transfected cells produced slow-growing and nonmetastatic tumors in syngenic or nude mice. These data indicate that NO decreased survival of tumor cells in the circulation and inhibited tissue invasion.

A hypothesis has been put forward suggesting that loss of $\mathrm{NO}$ from a biological cell could enable it to evade cell-cycle arrest and terminal differentiation, resulting in a premalignant cell or predisposed cell. A loss of $\mathrm{NO}$ from a malignant cell could result in uncontrolled cellular division. Since persistent vasodilatation is a specific feature in tumor vasculature and in the surrounding tissue, $\mathrm{N} O$ generated by the vascular endothelium in the proximity of or within the tumor, under the control of a local growth factor, could regulate the tumor blood flow via vasorelaxation. ${ }^{14,17}$ In addition, the role of $\mathrm{N} O$ in angiogenesis is well documented.

Cancer growth can be stimulated as well as inhibited by the immune system. The intratumor macrophage arginine metabolism is a molecular explanation for the dual ability of the immune system to inhibit or stimulate tumor growth. It has been proposed that arginine metabolism in the tumor bed yielding citrulline and $\mathrm{N} O$ favors tumor rejection, whereas production of ornithine and urea could promote tumor growth.

\section{Interactions between cytokines and nitric oxide}

0 ne of the first recognized natural mechanisms for regulating $\mathrm{N} O$ synthesis was IL4. W hen macrophages were activated with IFN $\gamma$ and a low dose of LPS, they produced significant amounts of $\mathrm{NO}$ and expressed high levels of NOS. This production and expression 
were inhibited in a dose-dependent manner by preincubating the cells with IL-4. IL-10 and TG Fb can also inhibit $\mathrm{N} O$ synthesis. In contrast, IFN $\gamma$ and TN F- $\alpha$, occupying their respective receptors, transmit a series of signals leading to the expression of $\mathrm{NOS}$ and the synthesis of $\mathrm{NO}$. In vitro, human MCP-1 was able to inhibit the production of $\mathrm{NO}$ by a macrophage cell line, suggesting that tumor-derived MCP-1 is likely to represent a mechanism for controlling $\mathrm{NO}$ mediated macrophage cytotoxicity, and for the recruitment and concomitant partial functional deactivation of TAM $\mathrm{s}$.

Advanced neoplasia has long been associated with defective capacity to mount responses to inflammatory stimuli. Thus, a balance between chemotactic and inhibitory cytokines may regulate infiltrate in tissues, including neoplasms. In this context, it is known that in mice IL-8 and TN F- $\alpha$ cause defective neutrophil recruitment when administered in the sistemic circulation, ${ }^{27-29}$ and the production of $\mathrm{NO}$ is involved in this inhibitory activity. ${ }^{30}$ This observation raises the possibility thatcytokines, leaking from advanced tumors, play a role in systemic defects of inflammation and immunity associated with neoplasia.

\section{REFERENCES}

1. Mantovani A. Biology of disease. Tumor-associated macrophages in neoplastic progression: a paradigm for the in vivo function of chemokines. Laboratory Invest 1994;71(1):5-16.

2. Negus RPM, Stamp GWH, Hadley J, Balkwill FR. Quantitative assessment of the leukocyte infiltrate in ovarian cancer and its relationship to the expression of C-C chemokines. Am J Pathol 1997;150:1723-34.

3. Mantovani G, Macciò A, Pisano $M$, et al. Tumor-associated lymphomonocytes from neoplastic effusions are immunologically defective in comparison with patient autologous PBMCs but are capable of releasing high amounts of various cytokines. Int J Cancer 1997;71:724-31.

4. Rabinowich $H$, Suminami $Y$, Reichert $T E$, et al. Expression of cytokine genes or proteins and signalling molecules in lymphocytes associated with human ovarian carcinoma. Int J Cancer 1996;68:276-84.

5. Bernasconi S, Matteucci C, Sironi M, et al. Effects of granulocytemonocyte colony-stimulating factor (GM-CSF) on expression of adhesion molecules and production of cytokines in blood monocytes and ovarian cancer-associated macrophages. Int J Cancer 1995;60:300-7.

6. Merogi AJ, Marrogi AJ, Ramesh R, Robinson WR, Fermin CD, Freeman SM. Tumor-host interaction: analysis of cytokines, growth factors, and tumor-infiltrating lymphocytes in ovarian carcinomas. Hum Pathol 1997;28:321-31.
7. Schondorf $T$, Engel $H$, Lindemann $C$, Kolhagen $H$, Von Rucker AA, Mallman P. Cellular characteristics of peripheral blood lymphocytes and tumour-infiltrating lymphocytes in patients with gynaecological tumours. Cancer Immunol Immunother 1997;44:88-96.

8. Melani C, Pupa SM, Stoppacciaro A, et al. An in vivo model to compare human leukocyte infiltration in carcinoma xenografts producing different chemokines. Int J Cancer 1995;62:572-8.

9. Mantovani A, Bottazzi B, Colotta F, Sozzani S, Ruco L. The origin and function of tumor-associated macrophages. Immunol Today 1992;13(7):265-70.

10. Goedegebuure PS, Douville CC, Doherty JM, et al. Simultaneous production of Thelper-1-like cytokines and cytolytic activity by tumor-specific T cells in ovarian and breast cancer. Cell Immunol 1997;175:150-6.

11. Negus RPM, Stamp GWH, Relf MG et al. The detection and localization of monocyte chemoattractant protein-1 (MCP-1) in human ovarian cancer. J Clin Invest 1995;95:2391-6.

12. Vitolo D, Zerbe T, Kanbour A, Dahl C, Herberman RB, Whiteside TL. Expression of mRNA for cytokines in tumour-infiltrating mononuclear cells in ovarian adenocarcinoma and invasive breast cancer. Int J Cancer 1992;51:573-80.

13. Naylor MS, Stamp GWH, Foulkes WD, Eccles D, Balkwill FR. Tumor necrosis factor and its receptors in human ovarian cancer. J Clin Invest 1993;91:2194-2206.

14. Chatwal VJS, Moochhala SM, Chan STF, Ngoi SS. Nitric oxide and cancer. Medical Hypotheses 1996;46:21-4.

15. Oshima $\mathrm{H}$, Bartsch $\mathrm{H}$. Chronic infections and inflammatory processes as cancer risk factors: possible role of nitric oxide in carcinogenesis. Mutation Res 1994;305:253-64.

16. Liu RH, Hotchkiss JH. Potential genotoxicity of chronically elevated nitric oxide: a review. Mut Res 1995;339:73-89

17. Bussolino F, Albini A, Camussi $G$, et al. Role of soluble mediators in angiogenesis. Eur J Cancer 1996;32A(14):2401-12.

18. Yim CY, Bastian NR, Smith JC, Hibbs Jr JB, Samlowski WE. Macrophage nitric oxide synthesis delays progression of ultraviolet light-induced murine skin cancers. Cancer Res 1993;53:5507-11.

19. Farias-Eisner R, Sherman MP, Aeberhard E, Chaudhuri G. Nitric oxide is an important mediator for tumoricidal activity in vivo. Proc Natl Acad Sci 1994;91:9407-11.

20. Edwards P, Cendan JC, Topping DB, et al. Tumor cell nitric oxide inhibits cell growth in vitro, but stimulates tumorigenesis and experimental lung metastasis in vivo. J Surg Res 1996;63:49-52.

21. Ambs S, Hussain SP, Harris CC. Interactive effects of nitric oxide and the p53 tumor suppressor gene in carcinogenesis and tumor progression. FASEB J 1997;11:443-8.

22. Thomsen LL, Lawton FG, Knowles RG, BeesleyJE, Riveros-Moreno $\mathrm{V}$, Moncada S. Nitric oxide synthase activity in human gynecological cancer. Cancer Res 1994;54:1352-4.

23. Xie K, Dong Z, Fidler IJ. Activation of nitric oxide synthase gene for inhibition of cancer metastasis. J Leukoc Biol 1996;59:797-803.

24. Mills $C D$, Shearer J, Evans R, Caldwell MD. Macrophage arginine metabolism and the inhibition or stimulation of cancer. J Immunol 1992;149(8):2709-14.

25. Liew FY. Interactions between cytokines and nitric oxide. Adv Neuroimmunol 1995;5:201-9.

26. Rojas A, Delgado R, Glaría L, Palacios M. Monocyte chemotactic protein-1 inhibits the induction of nitric oxide synthase in $\mathbf{J 7 4}$ cells. Biochem Biophys Res Commun 1993;196(1):274-9.

27. Otsuka $Y$, Nagano $K$, et al. Inhibition of neutrophil migration by tumor necrosis factor. Ex vivo and in vivo studies in comparison with in vitro effect. J Immunol 1990;145:2639-43.

28. Hechtman DH, Cybulsky MI, Fuchs HJ, Baker JB, Gimbrone Jr MA. Intravascular IL-8. Inhibitor of polymorphonuclear leukocyte accumulation at sites of acute inflammation. J Immunol 1991;147:883-92. 
29. Cunha FQ, Tamashiro WMSC. Tumour necrosis factor-alpha and interleukin-8 inhibit neutrophil migration in vitro and in vivo. Med Inflamm 1992;1:397-401.

30. Tavares-Murta BM, Cunha FQ, Ferreira SH. The intravenous administration of tumor necrosis factor al pha, interleukin 8 and macrophage-derived neutrophil chemotactic factor inhibits neutrophil migration by stimulating nitric oxide production. Br J Pharmacol, in press.

Beatriz Martins Tavares Murta - Associate Professor of the Discipline of Pharmacology, Department of Biological Sciences

J other Soares Machado - Undergraduate student of the Faculty of Medicine of Triângulo M ineiro

Mateus Zaparoli - Undergraduate student of the Faculty of Medicine of Triângulo M ineiro

Vítor Carvalho Lara - Undergraduate student of the Faculty of Medicine of Triângulo M ineiro
Eddie Fernando Candido Murta - Associate

Professor of the Discipline of $G$ ynecology and $O$ bstetrics, Faculty of Medicine of Triângulo M ineiro, Uberaba, MG, Brazil

Sources of Funding: N ot declared

Conflict of interest: $\mathrm{N}$ ot declared

Last received: 16 July 1998

Accepted: 10 ctober 1998

Address for correspondence:

Beatriz Martins Tavares M urta

Disciplina de Farmacologia,

Departamento de Ciências Biológicas,

Faculdade de Medicina do Triângulo Mineiro

Praça Manoel Terra, 330

Uberaba/MG - Brasil - CEP 38015-050

E-mail: beatrizmurta@mednet.com.br

Objetivos: A nalisar a complexa relação entre as células mononuclea res associadas ao tumor (TAM s) e as células neoplásicas, sendo resumidos sua competência imunológica, perfil da produção de citocinas e de óxido nítrico (N 0 ) no microambiente tumoral, com aspectos atuais de como a produção desses mediadores poderia afetar o crescimento tumoral.

Origem dos dados: $0 \mathrm{~s}$ dados foram obtidos de artigos indexados a través da rede M edline durante os últimos 10 anos. As palavras-chave utilizadas na pesquisa foram basicamente: câncer, carcinoma ovariano, citocina, óxido nítrico, células mononucleares, linfócito, macrófago. Seleção dos estudos e coleta dos dados: Foram revistos 30 trabalhos contendo dados relacionados à produção de citocinas e $\mathrm{N} O$ por TAM s e/ ou células neoplásicas e que tentaram estabelecer uma correlação entre a produção desses mediadores e o crescimento tumoral, particularmente no carcinoma ovariano. Resumo dos dados: As TAM s consistem principalmente de macrófagos e linfócitos T que apresentam baixo índice proliferativo e baixa citotoxicidade comparada aos monócitos autólogos do sangue, embora sejam capazes de liberar várias citocinas. 0 perfil da expressão de citocinas poderia ajudar a explicar tanto a deficiência imunológica observada em pacientes com carcinoma em fase avançada como também o potencial das TAMs em exercer atividade antitumoral, o que torna essas células um alvo para intervenção terapêutica. Além das citocinas, o N 0 também é produzido no microambiente tumoral. Várias observações em animais sugerem um papel tumoricida para o N 0 , mas em tumores humanos seu papel não foi estabelecido podendo ser alterado durante a progressão do tumor. 